\title{
Expression and Localization of Inducible and Endothelial Nitric Oxide Synthase in the Rat Ovary

\author{
Effects of Gonadotropin Stimulation In Vivo
}

Bradley J. Van Voorhis, ${ }^{\star}$ Kimberley Moore, ${ }^{\star}$ Paul J. L. M. Strijbos, ${ }^{5}$ Scott Nelson, ${ }^{\star}$ Sally A. Baylis, ${ }^{5}$ Dana Grzybicki, ${ }^{\ddagger}$ and Carl P. Weiner*

Departments of * Obstetrics and Gynecology and ${ }^{\ddagger}$ Pathology, University of Iowa College of Medicine, Iowa City, Iowa 52242-1080; and ${ }^{8}$ The Wellcome Research Laboratories, Beckenham, Kent BR3 3BS, United Kingdom

\begin{abstract}
Nitric oxide is reportedly involved in the regulation of several ovarian processes, yet the isoforms of nitric oxide synthase (NOS) expressed in the ovary are unknown. Our purpose was to identify and localize NOS isoenzymes in the rat ovary and to examine if mRNA expression of NOS isoenzymes change after gonadotropin stimulation. Using reverse transcriptase-PCR, we demonstrated that inducible (iNOS) and endothelial (eNOS), but not neuronal, NOS mRNAs are expressed in the ovary. In a gonadotropin-stimulated rat model, unstimulated ovaries had the highest levels of iNOS mRNA as quantified by ribonuclease protection assay. After gonadotropin injection, iNOS mRNA declined to undetectable levels in ovaries containing ovulatory follicles before increasing slightly in ovaries containing copora lutea. In situ hybridization studies localized iNOS to granulosa cells of secondary follicles and small antral follicles. Western blots of unstimulated ovaries demonstrated iNOS protein. In contrast to iNOS, eNOS mRNA levels, determined by quantitative PCR, increased after gonadotropin stimulation and peaked in ovaries containing ovulatory follicles before declining in the luteal phase. eNOS protein was localized to blood vessels in the ovary by immunohistochemistry. We conclude that two isoforms of NOS are expressed in the ovary and the mRNA levels for these isozymes are differentially regulated. (J. Clin. Invest. 1995. 96:27192726.) Key words: nitric oxide synthase • folliculogenesis • ovulation • corpus luteum • ovary
\end{abstract}

\section{Introduction}

The nitric oxide synthases (NOS) ${ }^{1}$ are a family of isozymes that catalyze the oxidation of $\mathrm{L}$-arginine to $\mathrm{NO}$ and L-citrulline.

Address correspondence to Bradley J. Van Voorhis, Department of Obstetrics and Gynecology, University of Iowa Hospitals and Clinics, Iowa City, IA 52242. Phone: 319-356-4536; Fax: 319-353-6659; E-mail: brad-van-voorhis@uiowa.edu

Received for publication 5 June 1995 and accepted in revised form 23 August 1995.

1. Abbreviations used in this paper: E2, estradiol; eNOS, endothelial NOS; hCG, human chorionic gonadotropin; iNOS, inducible NOS; nNOS, neuronal NOS; NOS, nitric oxide synthase; $\mathrm{P} 4$, progesterone; PMSG, pregnant mare serum gonadotropin.

\section{J. Clin. Invest.}

(C) The American Society for Clinical Investigation, Inc. 0021-9738/95/12/2719/08 \$2.00

Volume 96, December 1995, 2719-2726
NO has a variety of physiologic actions including the regulation of vascular tone, mediation of immune cell cytotoxicity, and neurotransmission $(1,2)$. NO synthases can be divided into two functional classes, "constitutive" and "inducible," based on their sensitivity to calcium (3). The constitutive forms, endothelial NO synthase (eNOS) and neuronal NO synthase (nNOS), bind calmodulin in a reversible and calcium-dependent fashion. Although termed constitutive, we have shown that estradiol increases calcium-dependent NO synthase activity and both eNOS- and nNOS-specific mRNA (4). The inducible form (iNOS) binds calmodulin tightly at resting intracellular calcium concentrations; its expression is induced by some toxins and by cytokines (5).

Several lines of evidence suggest that NO may regulate ovarian processes. We have previously demonstrated eNOS within human granulosa-luteal cells (6). Furthermore, NO inhibits granulosa-luteal cell steroidogenesis suggesting NO may be an autocrine regulator of steroid production (6). NO has also been implicated in the mechanism of ovulation. $\mathrm{IL}-1 \beta$ stimulates NOS activity in ovarian dispersates as measured by nitrite production $(7,8)$, and NO has been reported to potentially mediate the IL- $1 \beta$-induced tissue remodeling associated with ovulation (7). NOS inhibitors were reported to reduce the number of ova released in vivo in the rat (9). Recently, NO was shown to suppress apoptosis in cultured preovulatory ovarian follicles (10). It remains unclear which NOS isoenzymes are present in the rat ovary in vivo. The purpose of the present investigation was to determine which isoforms of NOS are present in the rat ovary and to localize their expression. We also sought to determine whether mRNA expression for NOS isoenzymes changes in the ovaries of immature rats stimulated with gonadotropins to mimic natural folliculogenesis, ovulation, and corpus luteum formation.

\section{Methods}

Detection of NOS isoform mRNA in the cycling rat. Mature, female rats (Harlan Sprague Dawley, Inc., Indianapolis, IN) were housed with a 14-h light, 10-h dark cycle. All rats were maintained and experimental protocols conducted in accordance with the University of Iowa Committee on Animal Care. Rats that were normally cycling as determined by daily vaginal smears (11) were killed on all days of the estrous cycle, and their ovaries were excised. mRNA was extracted from pooled ovaries (Fast Track mRNA isolation kit; Invitrogen, San Diego, CA) and quantified by spectrophotometry. For reverse transcriptase-PCR analysis, $1 \mu \mathrm{g}$ of mRNA was reverse transcribed with $1 \mu \mathrm{l}$ of Moloney murine leukemia virus reverse transcriptase (GIBCO-BRL, Gaithersburg, MD), $0.3 \mu \mathrm{g}$ oligo(dT) $>18$-mer primer (DNA facility, University of Iowa), a nucleotide mix (Boehringer Mannheim Biochemicals, Indianapolis, IN), and RNAsin (Promega Corp., Madison, WI) in a total vol of 30 $\mu \mathrm{l}$. cDNA was synthesized during a $1-\mathrm{h}$ incubation period at $37^{\circ} \mathrm{C}$. A 
50- $\mu$ l PCR reaction mix was prepared to amplify a 500-bp fragment of iNOS cDNA consisting of basepairs 1315-1814 (12), a 214-bp fragment of eNOS cDNA consisting of basepairs 244-457 (13), and a 472bp fragment of nNOS cDNA consisting of basepairs 4113-4584 (14). The primers used for iNOS were based on the rat sequence and were 5'-GCCTCCCTCTGGAAAGA-3' (sense), and 5'-TCCATGCAGACAACCTT-3' (antisense). The primers used for eNOS were based on the human sequence and were 5'-CAAGTTCCCTCGTGTGAAGAACTG-3' (sense) and 5'-TAAAGGTCTTCTTCCTGGTGATGCC$3^{\prime}$ (antisense). The primers used for the nNOS sequence were based on the rat sequence and were 5'-CTTCCGAAGCTTCTGGCAACAGCGACAATT-3' (sense) and 5'-GGACTCAGATCTAAGGCGGTTGGTCACTTC-3' (antisense). $5 \mu \mathrm{l}$ of the reverse transcription reaction was used per PCR reaction. Taq DNA polymerase and the accompanying $10 \times$ reaction buffer (Boehringer Mannheim Biochemicals) were used for amplification over 35 cycles of $96^{\circ} \mathrm{C}$ for $35 \mathrm{~s}, 56^{\circ} \mathrm{C}$ for $2 \mathrm{~min}$, and $72^{\circ} \mathrm{C}$ for $2 \mathrm{~min}$ and an $8-\min 72^{\circ} \mathrm{C}$ final extension period. Products were visualized on a $1 \%$ DNA agarose gel using ethidium bromide staining. PCR bands of the expected size were sequenced using an automated DNA sequencer (University of Iowa core DNA facility, Iowa City, IA).

Immature rat stimulation. The mature rat ovary is heterogeneous, containing developing follicles, ovulatory follicles, and corpora lutea simultaneously $(15,16)$. Therefore, to quantitate relative changes in NOS-specific mRNA at various time points during folliculogenesis, ovulation, and corpus luteum formation, we used a gonadotropin-stimulated immature rat model known to produce relatively homogeneous populations of these ovarian structures when compared to the mature rat ovary (17). Immature 23-d-old female rats (Harlan Sprague Dawley, Inc.) were obtained and fed chow and water ad lib. A 14-h light, 10-h dark cycle was maintained with the light cycle initiated at $0600 \mathrm{~h}$. Some of the rats were killed immediately while the remaining rats received a single subcutaneous injection of $20 \mathrm{IU}$ pregnant mare serum gonadotropin (PMSG; Sigma Chemical Co., St. Louis, MO). $48 \mathrm{~h}$ later, some of the rats were killed. The remaining rats received an ovulatory dose of $10 \mathrm{IU}$ human chorionic gonadotropin (hCG) (Sigma Chemical Co.), and then groups of these rats were killed 12, 24, and $72 \mathrm{~h}$ after the hCG injection. At each time point, ovaries were rapidly excised and frozen in liquid nitrogen for further analysis. Blood was also obtained by cardiac puncture and serum estradiol and progesterone concentrations were determined as previously described (18). Three separate experiments consisting of three rats per time point were performed for RNA analysis.

Ribonuclease protection assay for iNOS. A rat probe for iNOS was synthesized by cloning the 500-bp iNOS PCR product (see above) into a pT7Blue T-Vector (Novagen Corp., Madison, WI). Plasmid DNA was obtained from transformed competent cells using a standard miniprep protocol (19). Plasmid DNA was then purified and sequenced to determine insert orientation. Ribonuclease protection assays were performed using an antisense riboprobe for iNOS. An antisense riboprobe for glyceraldehyde-3-phosphate dehydrogenase (G3PDH; plasmid purchased from Ambion Inc., Austin, TX) was used as an internal standard since message levels for this enzyme do not change appreciably in ovarian cells after gonadotropin stimulation (20). Plasmids were linearized with EcoRI and riboprobes were synthesized using T7 RNA polymerase and $\left.{ }^{32} \mathrm{P}\right]$ UTP (T7 Riboprobe Gemini System II; Promega Corp.). The riboprobes were purified on a Quick Spin column (Boehringer Mannheim Biochemicals), separated on a $5 \%$ polyacrylamide, 8 $\mathrm{M}$ urea gel, and excised. The riboprobes were then eluted at $37^{\circ} \mathrm{C}$ for $2 \mathrm{~h}$ and recovered by ethanol precipitation. $1 \mu \mathrm{g}$ of mRNA was hybridized with $500,000 \mathrm{cpm}$ of iNOS riboprobe and $5,000 \mathrm{cpm}$ of G3PDH riboprobe for $15 \mathrm{~h}$ at $45^{\circ} \mathrm{C}$. This was followed by digestion with a 1:100 dilution of an RNase A/RNase T1 mix (Ambion Inc.) for $30 \mathrm{~min}$ at $37^{\circ} \mathrm{C}$ to digest single-stranded RNA. The resultant protected doublestranded hybrids were precipitated, separated on a $5 \%$ polyacrylamide gel, and then exposed to $\mathrm{x}$-ray film. The relative intensity of protected RNA bands was quantified by densitometric scanning.

In situ hybridization for iNOS. Cryostat sections $(12 \mu \mathrm{m})$ were prepared from ovaries which were frozen in liquid nitrogen. Sections were mounted onto gelatin-coated glass slides, fixed for $20 \mathrm{~min}$ in freshly made paraformaldehyde (2\%), washed in PBS, and dehydrated through a graded series of ethanol. Thereafter slides were stored at $-70^{\circ} \mathrm{C}$ until used.

Three synthetic oligonucleotides complementary to murine iNOS cDNA sequence were produced using an oligonucleotide synthesizer (Milligen 7500; Millipore Corp., Bedford, MA). A three-probe cocktail complementary to nucleotide bases $445-480,1257-1292$, and $1842-$ 1879 of the coding sequence of the murine iNOS cDNA was used throughout (21). Oligonucleotide probes were labeled with $\alpha-{ }^{35}$ S-dATP (Amersham Corp., Arlington Heights, IL) using deoxynucleotidyl transferase (GIBCOBRL, Grand Island, NY) in a total vol of $50 \mu \mathrm{l}$ consisting of $100 \mathrm{ng}$ oligonucleotide in $27 \mu \mathrm{l}$ diethyl pyrocarbonate-treated water, $10 \mu \mathrm{l}$ tailing buffer (GIBCO BRL), $1 \mu \mathrm{l}$ BSA (2\%) and $6.5 \mu \mathrm{l}$ terminal deoxynucleotidyl transferase $(15 \mathrm{U} / \mu \mathrm{l})$, as described previously (21). After incubation at $37^{\circ} \mathrm{C}$ for $8 \mathrm{~min}$, the reaction labeling was stopped by addition of $5 \mu \mathrm{l}$ EDTA ( $500 \mathrm{mM}$, Sigma Chemical Co.), and the enzyme was denatured by incubation of mixture at $70^{\circ} \mathrm{C}$ for a further $10 \mathrm{~min}$. Thereafter, the labeled oligonucleotide probes were purified by centrifugation through a chromatography column (G-25; Boehringer Mannheim Biochemicals), and stabilized in $40 \mathrm{mM}$ DTT.

Ovarian sections were hybridized as described previously (22). Briefly, sections were incubated with $50 \mu \mathrm{l} / \mathrm{cm}^{2}$ of hybridization solution consisting of dextran sulfate $(10 \%)$, Denhardt's solution $(1 \times)$, DTT $(0.1 \mathrm{M})$, tRNA $(0.25 \mathrm{mg} / \mathrm{ml})$, polyadenylic acid $(0.25 \mathrm{mg} / \mathrm{ml})$, denatured herring sperm DNA $(0.25 \mathrm{mg} / \mathrm{ml})$, deionized formamide (50\%), and $\alpha^{35} \mathrm{~S}-\mathrm{dATP}$-labeled oligonucleotide probes $(300,000 \mathrm{cpm} /$ $50 \mu \mathrm{l}$ per probe). Sections were covered with Scalon film (Fuji Photo Film Co., Tokyo, Japan) and incubated in a sealed moist chamber at $42^{\circ} \mathrm{C}$ for $18-20 \mathrm{~h}$. Thereafter, Scalon film was floated off in $1 \times$ SSC at room temperature after which the sections were washed twice in $1 \times \mathrm{SSC}$ at $55^{\circ} \mathrm{C}$, twice in $0.5 \times \mathrm{SSC}$ at $55^{\circ} \mathrm{C}$, and once in $0.5 \times \mathrm{SSC}$ at room temperature. DTT $(10 \mathrm{mM})$ was included in all SSC washing steps. Subsequently, sections were dipped in diethyl pyrocarbonatetreated water, dehydrated through ethanol, and apposed to $\beta$-max Hyperfilm (Amersham Corp.) for 3-4 wk. Films were developed and fixed in D19 (Eastman Kodak Co., Rochester, NY) and Unifix (Eastman Kodak) respectively. Cellular resolution of the hybridization signal was obtained by dipping sections into emulsion (LM-1 Hypercoat; Amersham Corp.) and exposing for 4-6 wk at $4^{\circ} \mathrm{C}$. After developing and fixing, sections were counterstained with Cresyl violet $(0.1 \%)$.

Western blot analysis for $i N O S$. Ovarian homogenates were prepared in the presence of protease inhibitors on ice, and total protein assays were performed (23). As a positive control, homogenates were prepared from RAW 264.7 cells (a mouse macrophage cell line) after cells were incubated with IFN- $\gamma(50 \mathrm{U} / \mathrm{ml})$ and LPS $(10 \mathrm{ng} / \mathrm{ml})$ which induce iNOS expression. $200 \mu \mathrm{g}$ of ovarian homogenate and $100 \mu \mathrm{g}$ of RAW cell protein were separated on an $8.0 \%$ SDS-polyacrylamide gel and transferred to a nitrocellulose membrane. The membrane was blocked with $1 \%$ milk and incubated with a 500 -fold diluted mAb against iNOS (anti-mac NOS; Transduction Laboratories, Lexington, KY). After washing and incubation with 5,000-fold diluted horseradish peroxidaseconjugated secondary antibody, iNOS was detected by enhanced chemiluminescence (ECL; Amersham Corp.).

Quantitative PCR for eNOS. Quantitative PCR for eNOS mRNA was performed by using heterologous internal controls. Heterologous DNA template (Bluescript SK [-]) was engineered to contain specific eNOS primer binding sites to yield a PCR product of $350 \mathrm{bp}$. One of the endothelial NOS primers was end-labeled with T4 polynucleotide kinase. $500 \mathrm{ng}$ of ovarian mRNA from each time point was then reverse transcribed as described above. $1 \mu$ l of the reverse-transcribed RNA, $10^{-3}$ attomoles of heterologous DNA template, and eNOS primers were added to each PCR reaction tube. 35 cycles of amplification were performed. This number of cycles had previously been determined by us to be in the linear phase of amplification for eNOS (unpublished data). The PCR products were then separated on a $1 \%$ agarose gel and quantified by excising the bands and counting the radioactivity in a scintillation counter. To account for variations in amount of reverse-transcribed RNA 


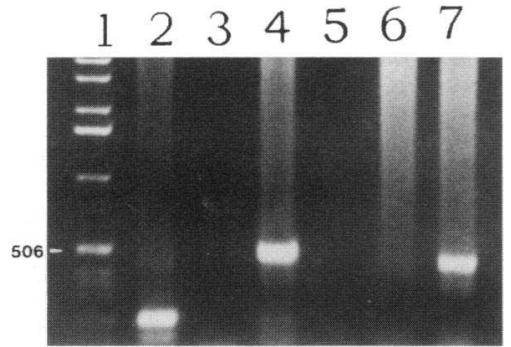

Figure 1. PCR amplification of reverse-transcribed RNA from mature rat ovary using primers for endothelial NOS, inducible NOS, and neuronal NOS. Lane 1 , DNA ladder, the 506-bp marker is noted; lane 2, the expected 214-bp product using endothelial NOS primers; lane 3, negative control of non-reverse-transcribed RNA, otherwise treated identically with PCR amplification using eNOS primers; lane 4, the expected 500-bp product using inducible NOS primers; lane 5, negative control of non-reverse-transcribed RNA, otherwise treated identically with PCR amplification using iNOS primers; lane 6, absence of PCR product from reverse-transcribed ovarian mRNA using neuronal NOS primers; lane 7, the expected 472-bp product when amplifying reverse-transcribed brain mRNA using neuronal NOS primers.

between samples, all eNOS data were normalized to G3PDH which was measured by the same technique, except that only 25 cycles of amplification were used, a number which was in the linear portion of the amplification curve for G3PDH. The primers used for G3PDH were based on the rat sequence (24) and were 5'-CATGACCACAGTCCATGCCATCAC-3' (sense), and 5'-CATGTAGGCCATGAGGTCCACCAC-3' (antisense).

Immunocytochemistry for eNOS. 5- $\mu \mathrm{m}$ frozen sections of ovaries were fixed in $4^{\circ} \mathrm{C}$ methanol for $15 \mathrm{~s}$. All subsequent steps were carried out in a moist chamber at room temperature. The slides were washed in PBS before adding $0.2 \%$ BSA in PBS for $10 \mathrm{~min}$. The primary antibody (diluted 1:25 in PBS) was added to the slides for $60 \mathrm{~min}$. This $\mathrm{mAb}$ was raised in mouse against a $20.4-\mathrm{kD}$ protein fragment corresponding to amino acids 1030-1209 of human endothelial NO synthase (Transduction Laboratories), and it has previously been shown to cross-react with rat eNOS (25). After PBS rinsing, FITC-conjugated secondary antibody (goat anti-mouse IgG; Pierce Chemical Co., Rockford, IL) was added to slides for $30 \mathrm{~min}$. After PBS washing, the slides were stained for $15 \mathrm{~min}$ in $4^{\prime}, 6$-diamidino-2-phenylindole (DAPI; Sigma Chemical Co.), a DNA-binding stain. The slides were then mounted and examined by fluorescent microscopy at a magnification of 600. Control coverslips had mouse nonimmune serum (Sigma Chemical Co.) substituted for the primary antibody.

\section{Results}

Presence of NO synthase mRNA isoforms in mature rat ovaries. Fig. 1 is a representative gel demonstrating the presence of eNOS (lane 2) and iNOS (lane 4) mRNA in mature cycling rat ovaries. Neuronal NOS mRNA could not be detected in the mature ovary (lane 6 ) although this isoform was easily detected in rat brain (lane 7). Neuronal NOS mRNA was also not detected in immature ovaries (results not shown). Non-reversetranscribed mRNA was used as a control for each amplification and was always negative, eliminating the possibility that genomic DNA accounted for the reaction product. Each of the PCR products was sequenced and results matched data for rat NOS isoform sequences $(12,14$, and Baylis, S. A., unpublished data ).

Characterization of gonadotropin-stimulated rat model. The ovarian histology observed at each time point was similar to that described by Peng et al. (17). Briefly, ovaries from untreated, 23-d-old rats were small and contained many primordial, primary, and secondary follicles, which contain no antral cavity. Serum estradiol (E2) and progesterone (P4) were below
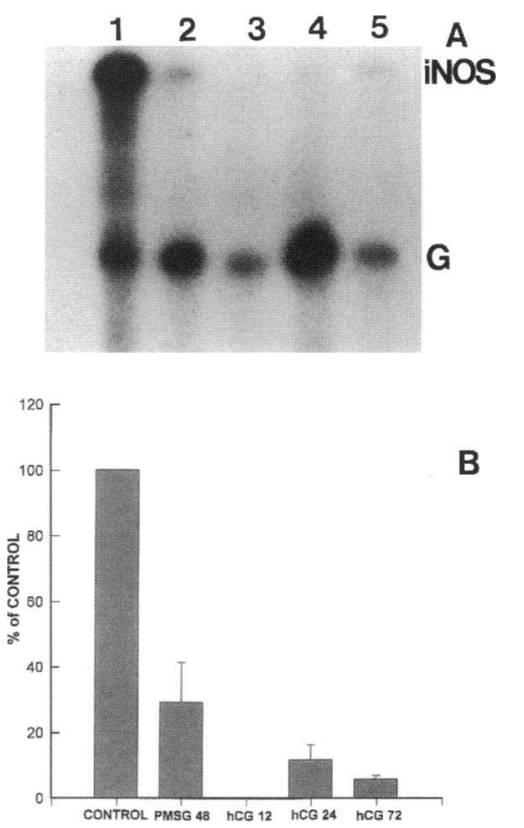

Figure 2. Effect of gonadotropin stimulation on inducible NOS expression in the ovary. (A) A representative ribonuclease protection assay gel. The 500-bp protected fragment of inducible NOS mRNA is labeled $i N O S$, the 316-bp protected fragment of G3PDH mRNA is labeled $G$. Lane 1, mRNA from unstimulated ovaries; lane 2, mRNA from ovaries containing antral follicles; lane 3, mRNA from ovaries containing ovulatory follicles; lane 4, mRNA from ovaries containing early corpora lutea; lane 5, mRNA from ovaries containing mature corpora lutea. $(B)$

The relative amounts of iNOS mRNA after gonadotropin stimulation determined in three separate experiments and expressed as mean \pm SD of control (unstimulated ovaries).

the level of detection. $48 \mathrm{~h}$ after PMSG injection, the ovaries had increased in size and contained predominantly large tertiary, antral follicles. The mean E2 was $359 \mathrm{pg} / \mathrm{ml}$ and the mean P4 was $4.6 \mathrm{ng} / \mathrm{ml} .12 \mathrm{~h}$ after hCG injections, there were many immediately preovulatory follicles with a thin apical region at the ovarian surface. The mean E2 was $73 \mathrm{pg} / \mathrm{ml}$, and the mean P4 was $10.8 \mathrm{ng} / \mathrm{ml}$. $24 \mathrm{~h}$ after hCG injection, early corpora lutea with small antral cavities predominated the histologic picture. The mean E2 was $110 \mathrm{pg} / \mathrm{ml}$ and the mean P4 was 20.2 $\mathrm{ng} / \mathrm{ml} .72 \mathrm{~h}$ after hCG, multiple mature corpora lutea with large luteal cells were found. The mean E2 was $15 \mathrm{pg} / \mathrm{ml}$ and the mean P4 was $60.7 \mathrm{ng} / \mathrm{ml}$.

Variation in iNOS mRNA in the gonadotropin-stimulated ovary. Ribonuclease protection assays were used to detect changes in iNOS mRNA in ovaries after gonadotropin stimulation. Fig. $2 A$ is a representative ribonuclease protection assay. iNOS mRNA was highest in the unstimulated immature ovary. $48 \mathrm{~h}$ after PMSG injection, iNOS mRNA was reduced to an average of $29 \%$ (mean reduction in three separate experiments) compared with unstimulated, immature ovaries after correcting for amount of G3PDH message in the samples (Fig. $2 \mathrm{~B}$ ). $12 \mathrm{~h}$ after hCG injection, iNOS mRNA was not detected by ribonuclease protection assay. 24 and $72 \mathrm{~h}$ after hCG injection, the ovaries contained a mean of 12 and $6 \%$ of the amount of iNOS mRNA compared with unstimulated, immature ovaries after correcting for G3PDH message in the samples (Fig. $2 \mathrm{~B}$ ).

Localization of iNOS messenger RNA in the ovary. In situ hybridization studies were performed on ovaries excised at the described time points. iNOS mRNA localized to the granulosa cell layer of secondary, preantral follicles found predominantly in the ovaries from unstimulated, immature rats (Fig. 3). It also was present in preantral follicles that failed to develop after gonadotropin stimulation in ovaries excised at other time points. iNOS mRNA was also localized to the granulosa cell layer of primary follicles although the signal was less intense than that 

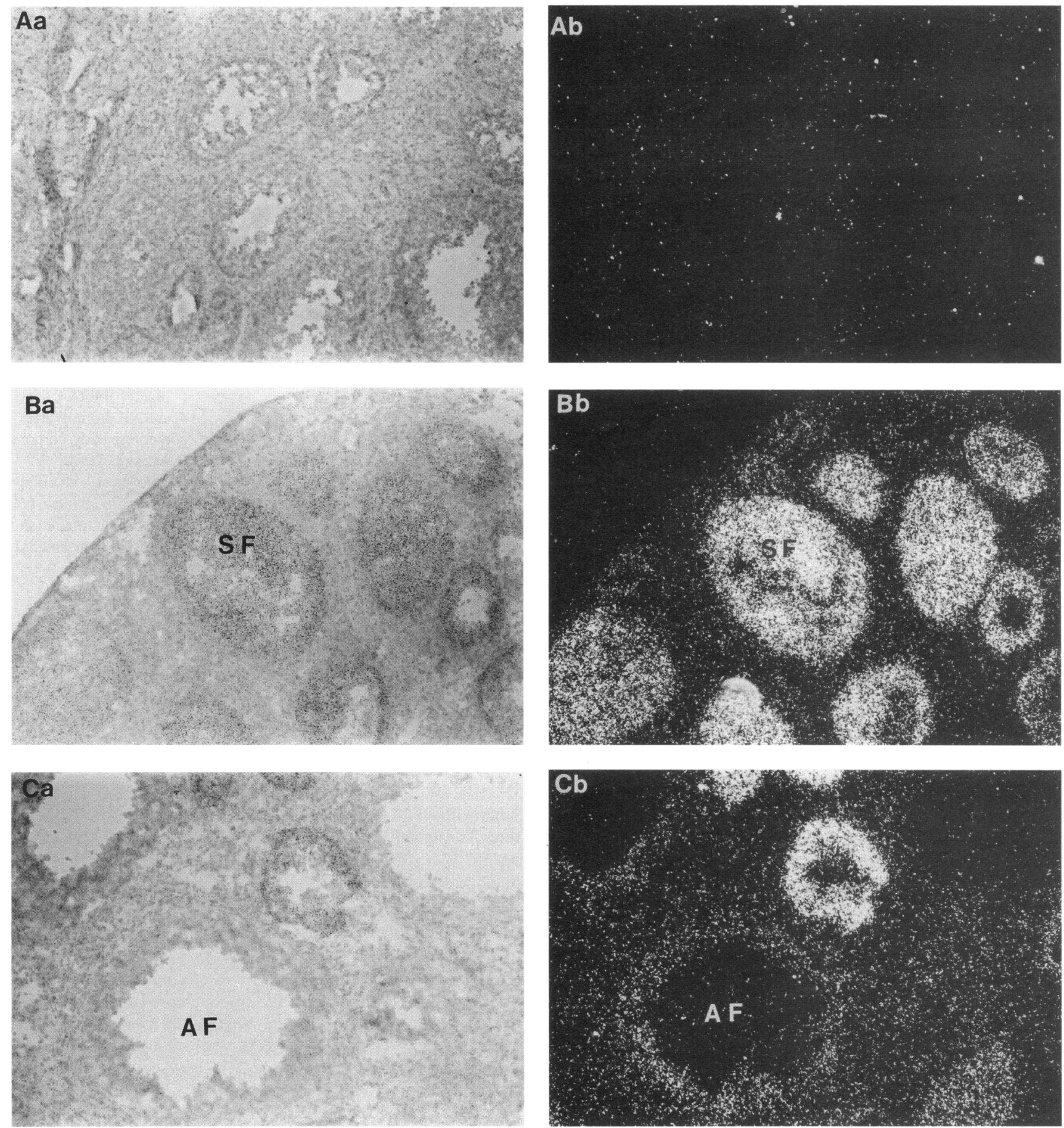

seen in secondary follicles (results not shown). The granulosa cell layer of some smaller antral follicles also contained iNOS mRNA, but the grain density was less than in secondary follicles (Fig. 3). No iNOS mRNA could be localized in large antral follicles, preovulatory follicles, early corpora lutea, mature corpora lutea, or any other cell type other than granulosa cells.

To reveal any nonspecific hybridization of the oligonucleotide probes used, the following control experiments were performed: (a) The cellular distribution of the hybridization signal obtained with the individual probes was compared with that obtained with the three-probe cocktail, and was found to give identical patterns of distribution (data not shown). (b) Tissue

sections were exposed to $100 \mu \mathrm{g} / \mathrm{ml}$ RNAse A before hybridization: this procedure abolished hybridization completely (see Fig. 3). (c) A 100-fold excess of unlabeled oligonucleotide probe was added to the hybridization solution: this procedure completely abolished hybridization signals (data not shown).

Detection of iNOS mRNA in the immature rat. Because iNOS mRNA expression has been reported to be uncommon in tissues before induction by infectious agents or cytokines (26), we sought to determine in which tissues iNOS was expressed using the ribonuclease protection assay. As seen in Fig. 4, iNOS mRNA could be detected in the ovaries and uterus but not in the adrenal gland or the brain of 23-d-old rats. We also could 

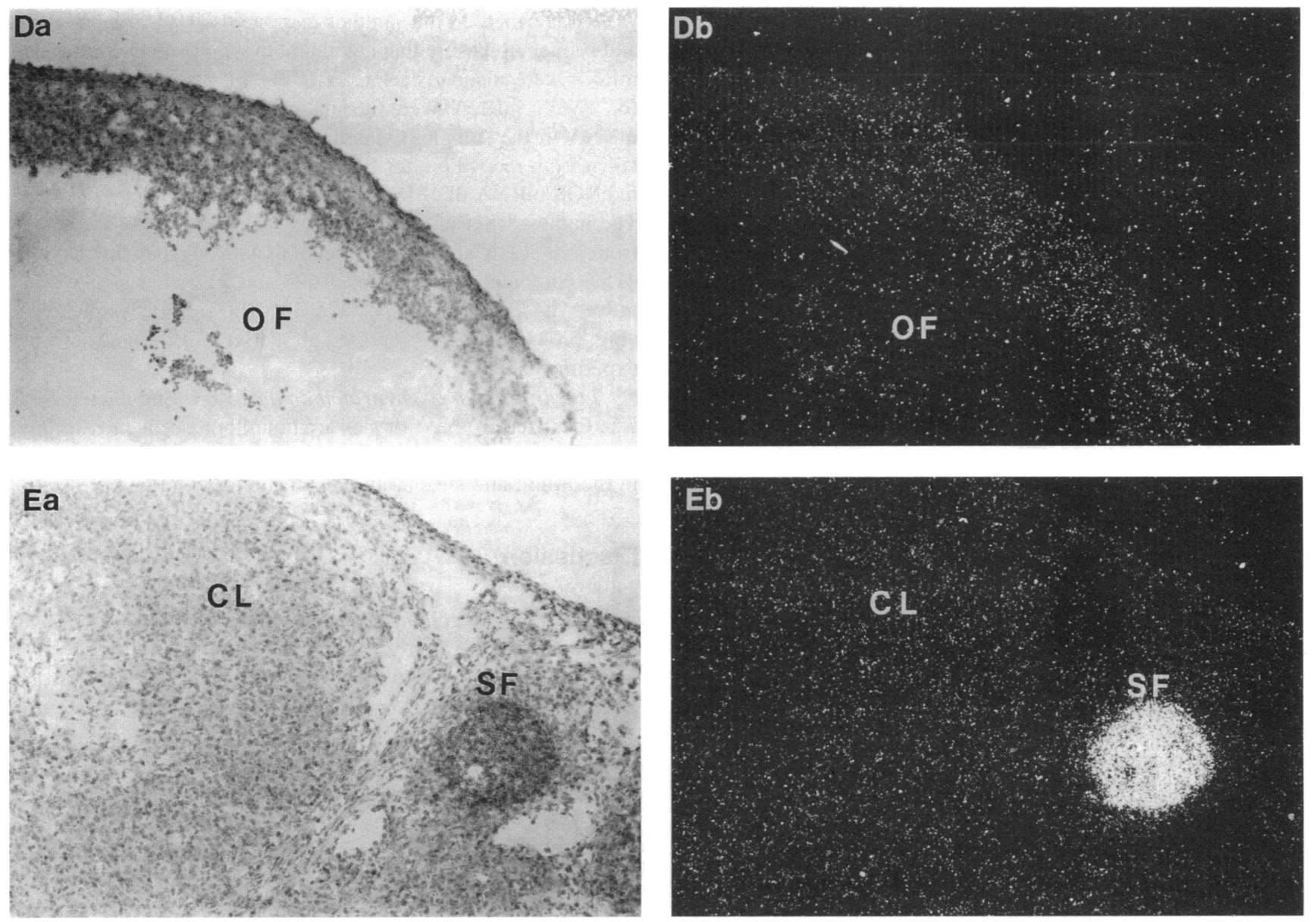

Figure 3. In situ hybridization slides using a probe for inducible NOS in the ovary. All photos to the left and labeled $(a)$ are the bright-field views $(\times 100)$. All photos to the right and labeled $(b)$ are the corresponding dark-field views allowing visualization of the iNOS probe. $(A)$ Negative control slide consisting of a section from an unstimulated ovary treated with RNAse before performing the in situ hybridization. There is no specific staining present. $(B)$ Section from an unstimulated ovary containing multiple secondary follicles $(S F)$ which show intense staining for iNOS. ( $C$ ) Section from an ovary taken $48 \mathrm{~h}$ after PMSG injection. Small antral follicles $(A F)$ still show specific staining for iNOS message but the grain intensity is not as great as in secondary follicles. $(D)$ Section from an ovary taken $12 \mathrm{~h}$ after hCG injection. The ovulatory follicle $(O F)$ shows no specific staining for iNOS. (E) Section of an ovary taken $72 \mathrm{~h}$ after hCG injection. The corpus luteum $(C L)$ shows no specific staining for iNOS while a secondary follicle $(S F)$ which did not respond to gonadotropin stimulation has intense iNOS staining.

not detect iNOS message in the rat kidney, liver, or skeletal muscle (results not shown).

Detection of iNOS protein in immature rat ovaries. We wanted to be certain that iNOS mRNA is translated into protein in the ovary. We therefore performed a Western blot analysis of protein from immature, unstimulated ovaries which had the

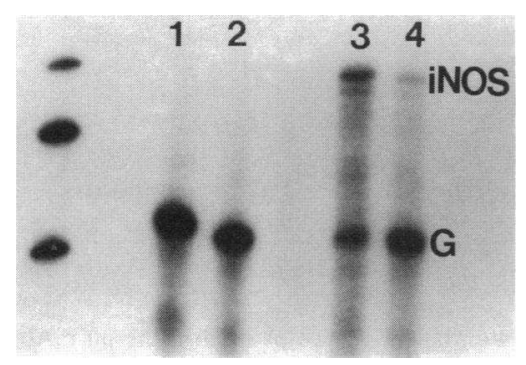

Figure 4. Ribonuclease protection assay gel for iNOS mRNA in the rat. A 500-bp protected fragment of inducible NOS mRNA ( iNOS) could be detected in the immature rat ovary (lane 3 ) and uterus (lane 4). Inducible NOS mRNA could not be detected in the rat brain (lane 1 ) or adrenal gland (lane 2). G3PDH mRNA (316 bp, G) could be detected in all samples and was included as an internal control. highest levels of iNOS mRNA expression (see above). Fig. 5 demonstrates iNOS protein in the ovary which has the same molecular weight as iNOS from stimulated RAW cells.

Variation in eNOS mRNA in the gonadotropin-stimulated ovary. To detect changes in eNOS mRNA in the ovarian cycle, we performed quantitative PCR assays on reverse-transcribed mRNA taken from ovaries at the same time points mentioned

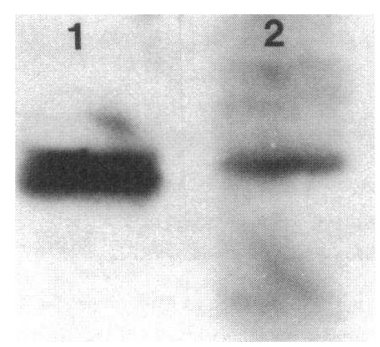

Figure 5. Western blot analysis of ovarian protein using an $\mathrm{mAb}$ to iNOS. Lane 1 is protein $130 \mathrm{KD}$ from RAW 264.7 cells stimulated in vitro to produce iNOS which serves as a positive control. Lane 2 is protein from unstimulated, immature

ovaries. A distinct band of the appropriate molecular mass is evident in this lane indicating the presence of iNOS protein in the ovary. 


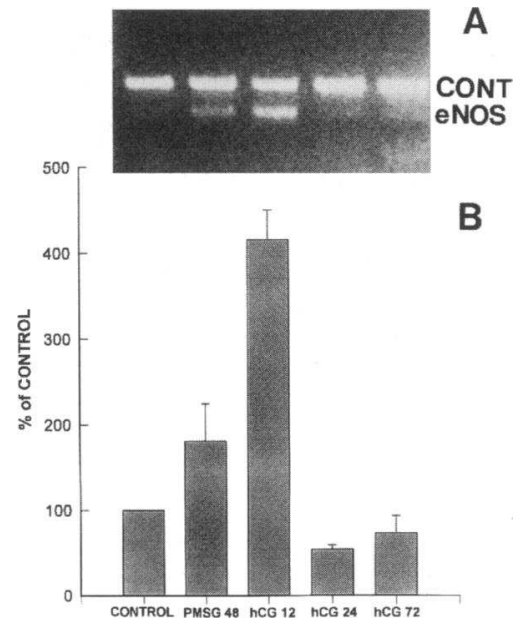

lated ovaries (control); follicles (PMSG 48); lane 3, mRNA from ovaries containing ovulatory follicles (hCG 12); lane 4, mRNA from ovaries containing early corpora lutea (hCG 24); lane 5, mRNA from ovaries containing mature corpora lutea (hCG 72). Distinct bands for eNOS could be visualized in all lanes when directly viewing the gel although, after reproduction, this may not be apparent in this photo. $(B)$ The relative amounts of eNOS mRNA after gonadotropin stimulation determined in three separate experiments and expressed as mean \pm SD of control (unstimulated ovaries).

above. Fig. $6 A$ is a representative agarose gel showing amplified product from the internal control (upper band) and eNOS mRNA in the sample (lower band). Separate amplifications were performed on the samples using G3PDH internal controls and primers to ensure that equal amounts of reverse-transcribed mRNA were added to each reaction (results not shown). Results for eNOS mRNA were normalized for amount of G3PDH mRNA in the sample. Quantitative PCR revealed that ovaries taken from rats $48 \mathrm{~h}$ after PMSG injection had a mean increase in eNOS mRNA of $181 \%$ compared with unstimulated ovaries. The highest level of eNOS mRNA was found in ovaries taken from rats $12 \mathrm{~h}$ after hCG injection with a mean increase of 415\% compared with control. At 24 and $72 \mathrm{~h}$ after hCG, eNOS mRNA had declined to 54 and $73 \%$ of control, respectively (Fig. $6 B$ ). The means reported are derived from three separate experiments.

Localization of eNOS protein in the ovary. Endothelial NOS was localized in the ovary by immunofluorescent microscopy. Specific staining could only be detected in blood vessels located in the hilum and stromal tissues of the ovary (Fig. 7).

\section{Discussion}

A wide range of cell functions has been attributed to NO. In this report, we demonstrate that NO produced by two NOS isozymes may have important physiologic roles in the ovary. Both iNOS and eNOS mRNA are expressed in the mature, cycling ovary. iNOS mRNA is expressed in the granulosa cells of primary, secondary, and small antral follicles in the ovary. Endothelial NOS protein is localized to the blood vessels in the ovary. The fact that mRNA levels of both isozymes change after gonadotropin stimulation of the ovary suggests they may have important roles in ovarian physiology.

Macrophages produce iNOS in response to microbial prod-
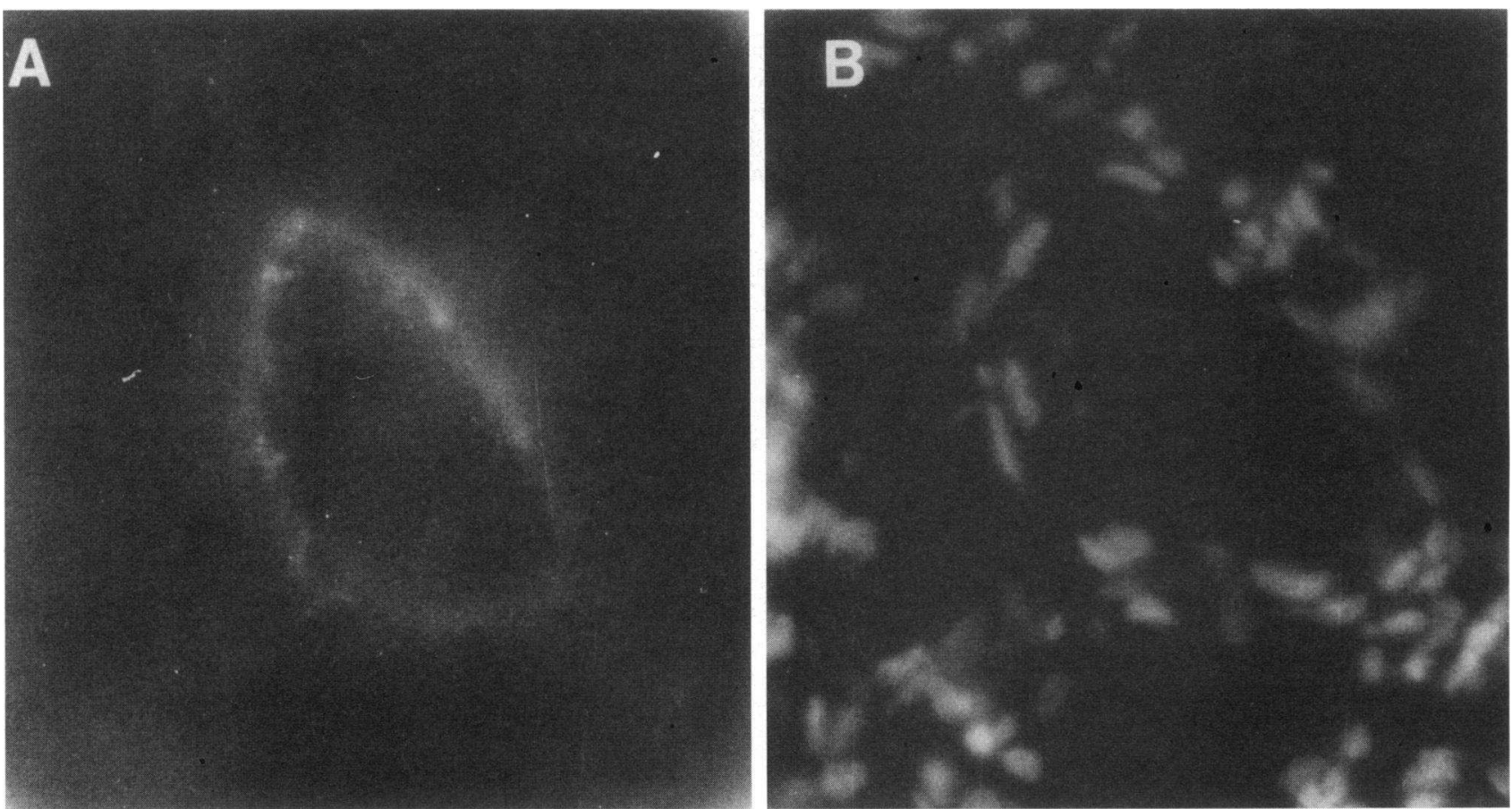

Figure 7. Immunohistochemical localization of eNOS in the ovary. $(A)$ Immunofluorescence in an ovarian hilar blood vessel when using an mAb to eNOS as the primary antibody. $(B)$ The same blood vessel as in $(A)$ using a different filter to visulize DAPI-stained nucleii which allows appreciation of the cellular architecture of the tissue. There was no flourescence in control slides when sustituting preimmune serum for the primary antibody (results not shown). $(\times 600)$ 
ucts and numerous cytokines, and NO mediates some of the cytotoxic actions of the activated macrophage (27). Inducible NOS expression can also be detected in a variety of other cell types after cytokine stimulation in vitro, but the expression of iNOS in normal tissues is relatively rare (28). Reported examples of tissues normally expressing iNOS include the rat uterus, the pregnant rabbit uterus, and large airways in humans (2729). In the present investigation, we demonstrate that the rat ovary also expresses iNOS and that its expression is predominantly in the granulosa cells of secondary, preantral follicles. Indeed, out of several tissues studied by ribonuclease protection assay, we could only detect iNOS expression in the ovary and uterus with the greatest amount of iNOS mRNA found in the ovary. Our findings support previous studies which have demonstrated the presence of NOS activity in whole ovarian dispersates from immature rats both before ( 8$)$ and after IL- $1 \beta$ stimulation $(7,8)$. We extend these observations by identifying iNOS as an isozyme expressed in the intact, in vivo ovary and by localizing expression by in situ hybridization methods.

Inhibitors of NOS when injected either intraperitoneally or into the ovarian bursae inhibit ovulation in the rat suggesting that NO is involved in the ovulatory process (9). Because there are no completely specific inhibitors of any particular isoform of NOS, the isoform involved in ovulation is uncertain. Our findings support a role for eNOS but not iNOS in the ovulatory process. eNOS mRNA expression peaks in ovaries containing ovulatory follicles. In contrast, iNOS mRNA reaches its nadir in ovaries containing ovulatory follicles, and we could not localize mRNA in the granulosa cells of large antral or ovulatory follicles. Given the profound vasodilatory effects of NO, it is likely that eNOS participates in ovulation by mediating some of the ovarian blood flow changes documented to occur in the periovulatory period (30). The evidence that iNOS is involved in ovulation has been indirect. Ellman et al. demonstrated that IL-1 $\beta$ induced ovarian dispersate cellular cytotoxicity was mediated by NO (7). Since IL-1 $\beta$ may be involved in the ovulatory process (31), Ellman et al. speculated that NO may be a physiologic mediator of the tissue remodeling events at ovulation. However, their findings were not confirmed by subsequent investigators who found that IL- $\beta$-induced ovarian cellular cytotoxicity was not mediated by NO (32).

In addition to ovulation, NO may have a physiologic role in other ovarian processes. We have previously shown that NO inhibits steroidogenesis in human granulosa-luteal cells in vitro and suggested that NO may be an autocrine regulator of steroidogenesis since eNOS was found in human granulosa-luteal cells by immunohistochemistry (6). In the current investigation, we were unable to localize eNOS in rat granulosa cells. This discrepancy may be explained by species differences but may also result from methodologic difficulties with the anti-human eNOS antibody being used on rat tissue sections as opposed to human cells grown in culture. Nevertheless, iNOS was localized to granulosa cells, and it is highly expressed at a time when steroidogenesis is virtually absent. This finding further supports the hypothesis that NO is an autocrine and inhibitory regulator of ovarian steroidogenesis. Another potential role of NO in the ovary is as an inhibitor of cell mitosis or possibly meiosis. In mouse macrophagelike cells, NO blocks the cell cycle at the $\mathrm{G} 2+\mathrm{M}$ phase (33). NO also inhibits mitosis of cultured vascular smooth muscle cells (34). Inducible NOS may play a similar role in the ovary by inhibiting follicular growth until gonadotropin stimulation results in decreased iNOS expression. Finally,
NO has recently been shown to reduce apoptosis in cultured ovarian follicles, thus acting as a follicle survival factor (10). Our finding of iNOS mRNA in the granulosa cells of primary and secondary, preantral follicles is consistent with this potential role of NO in vivo.

In conclusion, iNOS and eNOS are differentially regulated in the ovary. eNOS mRNA peaks in ovaries containing ovulatory follicles while iNOS-specific mRNA is at its nadir at this time. We speculate that the elevated estradiol concentrations seen after gonadotropin stimulation may lead to the induction of eNOS in the ovary as has been observed in other tissues (4). The mechanism by which gonadotropin stimulation inhibits iNOS mRNA in the ovary awaits further study.

\section{Acknowledgments}

We thank Sean Murphy, Frank Longo, and Jeanne Snyder, for help and advice with various aspects of this study.

This work was supported by the Berlex Scholar Award from the Berlex Foundation (B. Van Voorhis).

\section{References}

1. Moncada, S., R. M. J. Palmer, and E. A. Higgs. 1991. Nitric oxide: physiology, pathophysiology, and pharmacology. Pharmacol. Rev. 43:109-142.

2. Moncada, S. 1992. Ulf von Euler lecture: the L-arginine nitric oxide pathway. Acta Physiol. Scand. 145:201-227.

3. Nathan, C. and Q.-W. Xie. 1994. Nitric oxide synthases: roles, tolls, and controls. Cell. 78:915-918.

4. Weiner, C. P., I. Lizasoain, S. A. Baylis, R. G. Knowles, I. G. Charles, and S. Moncada. 1994. Induction of calcium-dependent nitric oxide synthases by sex hormones. Proc. Natl. Acad. Sci. USA. 91:5212-5216.

5. Nathan, C., and Q.-W. Xie. 1994. Regulation of biosynthesis of nitric oxide. J. Biol. Chem. 269:13725-13728.

6. Van Voorhis, B. J., M. S. Dunn, G. D. Snyder, and C. P. Weiner. 1994. Nitric oxide: an autocrine regulator of human granulosa-luteal cell steroidogenesis. Endocrinology. 135:1799-1806.

7. Ellman, C., J. A. Corbett, T. P. Misko, M. McDaniel, and K. P. Beckerman 1993. Nitric oxide mediates interleukin-1-induced cellular cytotoxicity in the rat ovary: a potential role for nitric oxide in the ovulatory process. J. Clin. Invest. 92:3053-3056.

8. Ben-Shlomo, I., E. Kokia, M. J. Jackson, E. Y. Adashi, and D. W. Payne. 1994. Interleukin- $\beta$ stimulates nitrite production in the rat ovary: evidence for heterologous cell-cell interaction and for insulin-mediated regulation of the inducible isoform of nitric oxide synthase. Biol. Reprod. 51:310-318.

9. Shukovski, L., and A. Tsafriri. 1994. The involvement of nitric oxide in the ovulatory process in the rat. Endocrinology. 135:2287-2290.

10. Chun, S. Y., K. M. Eisenhauer, M. Kubo, and A. J. W. Hsueh. 1995 Interleukin-1B suppresses apoptosis in rat ovarian follicles by increasing nitric oxide production. Endocrinology. 136:3120-3127.

11. Long, J. A., and H. M. Evans. 1922. On the Oestrus Cycle in the Rat and Its Associated Phenomena. University of California Press, Berkeley, CA. 17-21.

12. Wood, E. R., H. Berger, P. A. Sherman, and E. G. Lapetina. 1993. Hepatocytes and macrophages express an identical cytokine inducible nitric oxide synthase gene. Biochem. Biophys. Res. Commun. 191:767-774.

13. Janssens, S. P., A. Shimouchi, T. Quertermous, D. B. Bloch, and K. D. Bloch. 1992. Cloning and expression of a cDNA encoding human endotheliumderived relaxing factor/nitric oxide synthase. J. Biol. Chem. 267:14519-14522.

14. Bredt, D. S., P. M. Hwang, C. E. Glatt, C. Lowenstein, R. R. Reed, and S. H. Snyder. 1991. Cloned and expressed nitric oxide synthase structurally resembles cytochrome P-450 reductase. Nature (Lond.). 351:714-718.

15. Lane, C. E., and R. F. Davis. 1939. The ovary of the adult rat. I. Changes in the growth of the follicle and in volume and mitotic activity of the granulosa and theca during the estrous cycle. Anat. Rec. 73:429-437.

16. Bolling, J. L. 1942. Growth and regression of corpora lutea during the normal estrous cycle of the rat. Anat. Rec. 131-145.

17. Peng, X. R., A. J. W. Hsueh, P. S. LaPolt, L. Bjersing, and T. Ny. 1991. Localization of luteinizing hormone receptor messenger ribonucleic acid expression in ovarian cell types during follicle development and ovulation. Endocrinology. 129:3200-3207.

18. Van Voorhis, B. J., M. S. Dunn, J. R. Falck, R. K. Bhatt, M. Van Rollins, and G. D. Snyder. 1993. Metabolism of arachidonic acid to epoxyeicosatrienoic 
acids by human granulosa cells may mediate steroidogenesis. J. Clin. Endocrinol. \& Metab. 76:1555-1559.

19. Birnboim, H. C., and J. Doly. 1979. A rapid alkaline extraction procedure for screening recombinant plasmid DNA. Nucleic Acids Res. 7:1513-1517.

20. Reich, R., D. Daphna-Iken, S. Y. Chun, M. Popliker, R. Slager, B. C Adelmann-Grill, and A. Tsafriri. 1991. Preovulatory changes in ovarian expression of collagenases and tissue metalloproteinase inhibitor messenger ribonucleic acid: role of eicosinoids. Endocrinology. 129:1869-1875.

21. Lyons, C. R., G. J. Orloff, and J. M. Cunningham. 1992. Molecular cloning and functional expression of an inducible nitric oxide synthase from a murine macrophage cell line. J. Biol. Chem. 267:6370-6374.

22. Pratt, G. D., M. Kokaia, J.-M. Fritschy, H. Mohler, and O. Lindvall. 1993 Differential regulation of $N$-methyl-D-aspartate receptor subunit messenger RNAs in kindling-induced epileptogenesis. Neuroscience. 57:307-318.

23. Bradford, M. 1976. A rapid and sensitive method for quantitation of microgram quantities of protein utilizing the principle of protein-dye binding Anal. Chem. 72:248-254.

24. Fort, P., M. Piechaczyk, S. El Sabrouty, C. Dani, P. Jeanteur, and J. M Blanchard. 1985. Various rat adult tissues express only one major mRNA species from the glyceraldehyde-3-phosphate dehydrogenase multigenic family. Nucleic Acid Res. 13:1431-1442.

25. Dinerman, J. L., T. M. Dawson, M. J. Schell, A. Snowman, and S. H. Snyder. 1994. Endothelial nitric oxide synthase localized to hippocampal pyramidal cells: implications for synaptic plasticity. Proc. Natl. Acad. Sci. USA. 91:42144218.

26. Liu, S., I. A. Adcock, R. W. Old, P. J. Barnes, and T. W. Evans. 1993. Lipopolysaccharide treatment in vivo induces widespread tissue expression of inducible nitric oxide synthase mRNA. Biochem. Biophys. Res. Commun. 196:1208-1213.

27. Nathan, C., and Q. Xie. 1994. Nitric oxide synthases: roles, tolls, and controls. Cell. 78:915-918.

28. Sladek, S. M., A. C. Regenstein, D. Lykins, and J. M. Roberts. 1993. Nitric oxide synthase activity in pregnant rabbit uterus decreases on the last day of pregnancy. Am. J. Obstet. Gynecol. 169:1285-1291.

29. Huang, J., K. F. Roby, J. L. Pace, S. W. Russell, and J. S. Hunt. 1995. Cellular localization and hormonal regulation of inducible nitric oxide synthase in cycling mouse uterus. J. Leukocyte Biol. 57:27-35.

30. Ellinwood, W. E., T. M. Nett, and G. D. Niswender. 1978. Ovarian vasculature: structure and function. In The Vertebrate Ovary. R. E. Jones, editor. Plenum Publishing Corp., New York. 583-614.

31. Hurwitz, A., J. Loukides, E. Ricciarelli, L. Botero, E. Katz, J. M. McAllister, J. E. Garcia, R. Rohan, E. Y. Adashi, and E. R. Hernandez. 1992. Human intraovarian interleukin-1 system: highly compartmentalized and hormonally dependent regulation of the genes encoding IL-1, its recepter and its receptor antagonist. J. Clin. Invest. 89:1746-1754.

32. Ben-Schlomo, I., E. Y. Adashi, and D. W. Payne. 1994. The morphogenic/ cytotoxic and prostaglandin-stimulating activities of interleukin- $\beta$ in the rat ovary are nitric oxide independent. J. Clin. Invest. 94:1463-1469.

33. Takagi, K., Y. Isobe, K. Yasukawa, E. Okouchi, and Y. Suketa. 1994. Nitric oxide blocks the cell cycle of mouse macrophage-like cells in the early $\mathrm{G}_{2}+\mathrm{M}$ phase. FEBS. Lett. 340:159-162.

34. Garg, U. C., and A. Hassid. 1989. Nitric oxide-generating vasodilators and 8-bromo-cyclic guanosine monophosphate inhibit mitogenesis and proliferation of cultured rat vascular smooth muscle cells. J. Clin. Invest. 83:1774-1777. 